\title{
PERSISTING PROBLEMS IN NATIONAL CONTESTS AND ACTIVITIES
}

Chamman: Albert Willis, Executive Secretary, Illinois High School Association, Chicago, Illinois; Chairman, Committee on National Contests and Activities, NASSP

Panel:

Roland J. Lehker, Executive Secretary, Michigan Association of Secondary-School Principals, University of Michigan, Ann Arbor, Michigan

Charles H. Downs, Principal, High School, Arlington, Massachusetts J. H. Duncan, Principal, Byrd High School, Shreveport, Louisiana W. G. Eismon, Executive Secretary, West Virginia Secondary School Activities Commission, Charles Town, West Virginia

George R. Perry, Principal, Eastern High School, Bristol, Connecticut Raymond S. Locke, Principal, High School, Barrington, Rhode Island

\section{Summary of the presentation made by ROLAND J. LEHKER}

For contests and activities in high schools into proper focus. Although the regulation of athletic activities has been conducted by the National Federation of State High-School Athletic Associations, the regulation of non-athletic activities is not firmly established. This does not mean, however, that progress has not been made in the control of such activities. Much progress has been made toward selecting contests and activities which contribute to the educational welfare of students. This progress is indicated by the cooperation now existing between sponsoring agencies and the contests and activities committees (both state and national), the reduction in the number of national contests, the reduction in the number of essay contests, and the application of the national criteria to insure wholesome contests and activities.

A large number of problems still persist. The problems in fact have been compounded as these committees have become effective. As contests have been rejected and schools denied participation in certain activities, pressures have been brought to bear by lay and school groups. It is necessary to look at the progress which has been made in order to discover which continuing problems should be attacked.

1. Contest and activity committees generally have a reputation for acting as limiting and inhibiting agencies. However, educators today

Roland J. Lehker is Executive Secretary of the Michigan Association of Secondary-School Principals, 3501 Administration Building, University of Michigan, Ann Arbor, Michigan. 
feel that much education takes place outside the classroom, that various forms of motivation should be used and that many devices and techniques should be used to interest students. How can contest and activities committees encourage the use of contests and activities to motivate and interest students?

2. Contest and activities committees favor the reduction or elimination of essay contests. Is there not some value in these activities as a motivational device? How are essays different from other forms of "creative writing"? How can "creative activities" be evaluated? Are examinations a proper substitute for "creative writing"?

3. At present the rulings of the contest and activities committee are "voluntarily" followed except in certain accredited schools. Should there be an enforcing agency? What should be the relationship of contest and activity committees to the National Federation of State High-School Athletic Associations?

4. There is a tendency for some principals to consider contest and activities committees as a "whipping boy." How can principals work more closely with these committees? Would it be valuable for schools to have committees consider contests and activities rather than having forceful, ambitious, persuasive teachers make decisions in their fields without regard for the over-all school program? Perhaps contest and activities committees within a school or school district are needed to operate within the framework of the state and national body.

5. Colleges and universities have greatly increased the activities which they provide for high-school students. How can these be effectively controlled, coordinated, and used?

6. At present the distance traveled by students is often limited by contest and activities committees. Out-of-state travel is generally discouraged. With modern means of transportation, are these restrictions realistic? If "travel is broadening," should it be encouraged if proper protection is guaranteed for classroom work?

This list of six problem areas indicates that not all of the problems have been solved. Perhaps one of our greatest needs is to share information among states so that all may profit from the gains which have been made by each. Our goal should be not only to regulate and control activities to protect students from exploitation, but also to use outside sources in the community and nation to further educational development. 


\section{Summary of the presentation made by CHARLES H. DOWNS}

B

ASED on the past three years it could be stated that pressures on schools in regard to national contests and activities are in control to some extent. This statement is based on the approved lists of National Contests and Activities issued by the Committee on National Contests and Activities of the NASSP for 1958-59, 1959-60, and 1960-61. A recapitulation of the various categories listed give the following results:

\begin{tabular}{lccc}
\hline & $1958-59$ & $1959-60$ & $1960-61$ \\
\hline Agriculture contests & 3 & 0 & 0 \\
Art contests & 6 & 6 & 6 \\
Editorial and writing contests & 9 & 8 & 8 \\
Exams and scholarships & 22 & 21 & 21 \\
Home ec. and ind. arts & 4 & 4 & 3 \\
Speech contests & 6 & 6 & 6 \\
Miscellaneous & 6 & 6 & 6 \\
National activities (not contests) & 14 & 21 & 20 \\
Total & 70 & 72 & 70 \\
\hline
\end{tabular}

These figures would show a definite situation of stability at least. However, the fact remains that there is a total of 70 approved contests or activities for 1960-61 which is the same total for 1958-59.

The encouraging fact of the 1960-61 total is that it overcame the jump to 72 for the 1959-60 listing and could possibly mean that the NASSP Committee on National Contests and Activities will continue to reduce the totals in ensuing years.

This report is ignoring any state or regional contest but would like to insert the idea that the desk of the average principal is deluged with local, state, and regional announcements of contests and activities over and beyond those of national scope. Accordingly, the blessings of all principals would be directed to the National Committee for any efforts to reduce radically the national listings.

This discussant heartily approves the recommendation by the National Committee under the heading of "Policy for all Secondary Schools"; namely: "That all secondary schools take a firm and consistent position against participating in unapproved national contests or activities." That action is obviously in process on the part of the National Committee is evidenced by a report given by Ellsworth Tompkins, in July 1959, at the National Federation Annual Meeting held at Lookout Mountain, Tennessee. This report highlighted the problems, especially with essay contests, duplication of contests, sub-contests under one sponsorship and the

Charles H. Downs is Principal of the Arlington High School, Arlington, Massachusetts. Enrollment, 2,040. 
pursuance by the Committee of sufficient information to determine the reliability of the sponsor. Furthermore, it would seem that the greatest increase promised at that time and demonstrated by the figures submitted above shows that there has been a great increase in National Activities such as conventions, conferences, etc., which do not give prizes or awards. The greatest difficulty in this particular category is the question of released time from school days.

This discussant believes that the policy of annual listings which implies that an approved activity is for only one year serves as an excellent possibility for tight controls and steady reduction. As has been intimated previously, contests and activities on the local, state, and regional areas in my part of the country are not in as well-organized control as those on the national level. It is the belief of this discussant, therefore, that the progress made on the national level should be copied on the local levels.

\section{Summary of the presentation made by J. H. DUNCAN}

\section{$\mathrm{T}$}

HE prinicpals and teachers of the secondary schools of Louisiana appreciate the fact that the National Association of Secondary-School Principals reviews the many national contests and activities and makes specific recommendations concerning them. To have a united stand either for or against a given contest or activity is a definite and comforting service. The Association's recommendations have greatly reduced the pressure on all principals. However, pressure continues to be exerted by contests or activities that are not national in scope.

We do not have a state-wide organization in Louisiana that governs school activities other than athletics. Consequently, each school system must provide its own method of control. It is my purpose here to give a brief account of the strategy adopted by the school system in which I am employed. (With three exceptions, all public schools in Louisiana operate under a parish [county] system.)

Any outside group or organization that wishes to place a program or activity in the school system must follow a definite procedure.

1. It must appear before an Educational Council composed of seven elementary-school teachers, seven junior and senior high-school teachers, two elementary-school principals, one junior high-school principal, one senior highschool principal, one rural-school principal, and two members of the central office staff. The sponsoring organization must explain the program to the committee and answer any question the school personnel might wish to ask. The committee, in executive session, either approves or disapproves the program. In evaluating these applications, this Educational Council employs standards similar to those used by the National Association of Secondary-School principals.

J. H. Duncan is Principal of the C. E. Byrd High School, Shreveport, Louisiana. Enrollment, 1,900. 
2. If the above mentioned committee gives its approval, then the sponsoring organization must repeat the same procedure before the school board. If the school board gives its approval, then the sponsors of the program may contact the principals of the schools. Needless to say, many sponsors of "flyby-night" contests and activities drop their interest in the schools upon being notified of this required procedure.

At first glance one would think that this completely ties the hands of the principal in the operation of his school. Such is not the case. The principal has the right to accept or reject any approved contest or activity as far as individual school is concerned. Also, note that this procedure applies only to those requests that originate outside of the school. We find that this policy supplements quite well the policy of the National Association of Secondary-School Principals.

During the past year, the Caddo Parish School Board took two steps to strengthen this policy. The first step prohibits the handing out of questionnaires to pupils at school without the approval of the school board. The second step was taken after the problem had been studied for a year by classroom teachers, principals, members of the central office staff, and school board members. Following their recommendations, drives for membership and for money, as well as many other activities, were eliminated from the school day.

In summary, the united strength of the National Association of Secondary-School Principals acting as a bulwark against national pressures on schools is invaluable. Speaking for the state of Louisiana, permit me to say again that the principals and teachers are grateful for the leadership of this organization. Both national and local school groups must continue their vigilance against encroachments and provide the necessary means of control. The school day must be devoted to academic achievement.

\section{Summary of the presentation made by W. G. EISMON}

\section{$\Upsilon_{\text {HE real objectives of an activities program are: }}$}

1. To stress the cultural values, the appreciations, and skills involved in all interscholastic activities, and to promote cooperation and friendship

2. To limit interscholastic programs as to both character and quantity to such activities and such events as may reasonably be expected to promote the generally accepted objectives of secondary education, and as shall not unduly interfere with nor abridge the regular program of teachers and students in the performance of their regular day-to-day school duties

W. G. Eismon is Executive Secretary of the West Virginia Secondary-School Activities Commission, Charles Town, West Virginia. 
3. To encourage economy in the time that student and the teacher personnel devote to interscholastic activities

4. To encourage economy in expenses to interscholastic activities

5. And, to discourage long trips for large groups of students.

If these objectives are to be met, careful planning on the part of school officials should be made and the state activities commission should do all in its power to protect pupils and schools from placing too much stress on the so called, co-curricular program by the school under its supervision.

Each year the secondary schools of the United States are requested and urged to participate in every conceivable type of contest or activity imaginable. Needless to say the real control of such contests and activities rests with the principal of the school. However, much help and guidance can be provided by the state office providing school officials are willing to cooperate. Schools should be permitted to participate only in those activities approved by the state activities association.

In many states a list of approved activities and contests are placed in the hands of the principal at the beginning of the school term each year by the commission. Schools are asked to refrain from participating in activities that are not on this approved list and, in many cases, failure to abide by the rules and regulations lead to disciplinary measures. While this is perhaps the most undesirable way to keep schools from participating in non-approved activities, it is, no doubt, the most forceful.

Since the educational program of a good secondary school gives pupils enough work to keep them busy, a limited number of approved contests and activities approved by the State Activities Commission is most desirable. As a result, an activity should supplement the regular school program of those students participating. Schools should refrain from permitting pupils to participate in any essay contest because of educational value derived from such activity. If that be true, why should an essay contest be approved by the state association or the Committee on $\mathrm{Na}$ tional Contests and Activities?

Certainly other precautions should be taken in approving contests or activities that have undesirable features. Contests should be rejected which require the participating students to pay entrance fees, and those that envolve excessive travel for large groups of students should be discouraged. Many state associations are unalterably opposed to those activities or projects requiring fees from students and reject them without hesitation.

State associations are certainly in their right rejecting those contests which are designed to benefit the promoter more than the participating student as well as those motivated primarily by monetary appeal.

In formulating a list of approved contests and activities for member schools, a state activities commission should sanction or approve only those events which: (1) meet standards, (2) which take little or no school time, and (3) which do not exploit pupils. 


\section{Summary of the presentation made by GEORGE R. PERRY}

HE Connecticut's Secondary-School Principals' Association has a Board of Control for Interschool Activities. It operates on the state level much as does NASSP's national committee, using criteria which are similar to those of NASSP. It is, perhaps, less lenient in some respects; for example, it is less willing to approve activities which take place on Sunday or which cause a loss of school time.

After drawing up an annual master list of approved activities, the state committee confers monthly and issues its report by sending a postal card to each high-school principal. This monthly mimeographed card lists as "approved" or "not approved" any contests or activities which have been brought to the attention of the committee during the preceding four weeks.

Out of loyalty to NASSP, this group of Connecticut principals endorses automatically all national contests and activities on the NASSP approved list, though sometimes with tongue in cheek. Local dissatisfaction, for example, has been experienced with such nationally approved contests as the National Red Cherry Institute's Pie Baking Contest, the D.A.R. Good Citizen Award, and the Junior Chamber of Commerce script writing contest on the theme, "My True Security."

There has been a great increase lately in the number of events scheduled in school time. Some of these are Model Congresses or Open Houses run by colleges; some are conventions of organizations. Influenced by the state activities committee, most sponsors have re-scheduled their events to late afternoon and evening or to Saturdays.

More resistance has been experienced from such organizations of teachers as those which sponsor the Scholastic Press, Federation of Student Councils, and the All-State Music Festivals. A rather reluctant cooperation has been secured from the sponsors of the Distributive Education Clubs, the Future Farmers of America, and the Future Homemakers of America. Gradually, however, these organizations have been persuaded to set their meetings so that little or no school time is lost.

Of concern to Connecticut's committee, however, are the national conventions, approved by NASSP, which meet in school time. These are the conventions of the Future Farmers of America, Future Business Leaders of America, Music Educators' National Conference, and the Williamsburg Student Burgesses, to name a few. Connecticut principals cannot understand why these cannot be held in the summer vacation. Some principals, moreover, question the justification of national conventions anyway.

George R. Perry is Principal of Bristol Eastern High School, Bristol, Connecticut. Enrollment, 1,406. 
Fully half of the activities which come before the Connecticut Board of Control are not found on the national list. Did they apply, only to be turned down, or have they never made application to NASSP? If the latter is the case, and the contest has originated since the most recent meeting of the national committee, it may be that a worth-while contest is being penalized by the necessary delay until the following May. This may not be important. However, this state's committee occasionally gives tentative approval, pending the next meeting of the NASSP committee. Of great help to the state committee would be an annual list of those contests and activities which have been rejected by NASSP.

Much attention has been devoted to local radio and television programs involving youth. These take various forms, and have varying degrees of merit. Turned down have been competitions between teams, along the line of the College Quiz Bowl. Most programs of the "Bandstand" type are blacklisted. Most objectionable feature is the identification of individuals as representatives of $\mathrm{X}$ High School. Too often the pupil is an unsavory-looking character who is an unfortunate choice as a symbol of the typical student of X High School. At least one station manager has cooperated by eliminating all school identifications.

Perhaps a more serious objection to this type of program is the exploitation of youth to sell a product. Seldom are these run as sustaining programs, and there is the ever-present danger of unhealthy commercialism.

Very often the contest or activity requires considerable travel. This is usually true of debate tournaments, speaking contests, musical auditions, cheerleading clinics, etc. The state committee insists that all such travel be chaperoned by teachers and in adequately insured vehicles. It strongly deplores the use of student drivers at any time.

Connecticut's Board of Control has experienced many pressures, of varying severity, from those who do not like to be balked. A few are selfish promoters more interested in propaganda or in selling a product than in the welfare of teenagers. Many who protest are well-meaning sponsors, often teachers, who deprecate the importance of certain items in the list of criteria.

The strength of this supervising body has brought comfort to harassed principals. It has relieved them of the occasional embarrassment in having to refuse their constituents permission to participate in an activity that the administration felt to be unwholesome. It has removed the pressures exerted by townspeople, teachers, and students and substituted the authoritative voice of the state association's Board of Control. In other words, it has taken the principal "off the hook!" 


\section{Summary of the presentation made by RAYMOND S. LOCKE}

$\mathrm{T}_{\mathrm{H}}$

HE secondary school is continually being called upon by individuals and organizations to offer activities which to many seem of more value to the sponsor than the student. It is a primary function of the NASSP committee to keep the school's educational aims and such secondary activities, as they may be called upon to perform, in the proper educational perspective.

The committee on contests and activities is made up of six secondaryschool administrators who meet annually to consider applications to be approved for the coming year of contests and activities involving more than five states. All of the above are approved on a one-year basis. The purpose of the committee is to study carefully all requests and, after thorough consideration, establish an approved list to serve as a guide for you to follow. The placing of an activity on the list does not mean that you are obligated to participate. The approved list gives you a reasonable argument against involving your students in those activities not approved by the committee.

Over the past several years the committee has developed policies which provide the opportunity for student participation under proper school control. Several of the policies are:

1. The consideration of an activity only when the proper application forms, as supplied by the national office, is submitted in full.

2. The curtailing of further essay contests. This type of a contest is difficult to judge, often becomes an administrative burden, involves teachers' time, and has on numerous occasions promoted plagiarism.

3. Strongly recommend the competitive examination as a method of selecting outstanding students. winners.

4. The urging of sponsors to increase the amount to be realized by the

5. Whenever possible, the committee has discouraged the giving of cash awards, emphasizing the increased need of scholarship assistance to be paid directly to the college. Further offering the services of the National Association to administer scholarship funds.

6. Minimizing the number of activities which take students away from school when it is in session.

7. Due to the need of adequate supervision when students are at a large convention, the committee discourages any group of more than fifty participants assembling for a national awards gathering.

8. The inviting of the sponsoring agency to meet with the committee. This has been adopted for all new requests for approval. Each year the committee meets with representatives who request to bring to the committee anticipated changes, receive suggestions for a better program, etc.

Raymond S. Locke is Principal of Barrington Senior High School, Lincoln Avenue, Barrington, Rhode Island. Enrollment, 540. 
In the vast majority of cases, sponsoring agencies are enthusiastic in their desire to assist our youth and are most receptive to the committee's suggestions. As an administrator, you can greatly assist in the work of the committee through your cooperation with those who sponsor the approved activities, apprising the committee of any variance from correct procedure, and alerting the national office of any individual or organization who seeks to impose demands upon your school.

\section{DEVELOPING TOMORROW'S LEADERS TODAY THROUGH THE NATIONAL HONOR SOCIETY}

Chairman: Howard F. Horner, Principal, David Douglas High School, Portland, Oregon

INTERROGATORS:

Leslie M. Evans, Principal, Central High School, Columbus, Ohio

George E. Miller, Principal, Senior High School, North Little Rock, Arkansas

W. Eugene Smith, Principal, High School, Orangeburg, South Carolina

\section{Summary of the presentation made by FRANK A. PEAKE}

\section{Tr}

\section{The National Honor Society Scholarship Program}

LHE National Honor Society stands unique among the organizations in the secondary schools in that it has not varied from its purpose since its establishment in 1921. The purpose of the National Honor Society as stated in Section II of Article I in the Constitution is, "The purpose of this organization shall be to create an enthusiasm for scholarship, to stimulate a desire to render service, to promote leadership, and to develop character in the students in the secondary schools of the United States."

For a number of years, scholarship was in disrepute and mediocrity seemed to hold the upper hand. In the face of this heavy harrage of public opinion among school people, the National Honor Society has stood firm and has insisted on selecting and honoring those in our high schools who stood out from among the crowd and proclaimed high ideals and true scholarship.

When the tide changed and there was once again an insistence on scholarship in our schools, those principals who had chapters of the National Honor Society were in an enviable position in that they had an organization established and functioning within their schools through which they could promote and encourage this changed procedure. This

Frank A. Peake is Principal of Shades Valley High School, Birmingham, Alabama; Chairman of National Honor Society Scholarship Board, NASSP. 